\title{
Biodiversity surveys and stable isotope analyses reveal key differences in intertidal assemblages between tropical seawalls and rocky shores
}

\author{
Samantha Lai ${ }^{1}$, Lynette H. L. Loke ${ }^{1}$, Tjeerd J. Bouma ${ }^{2}$, Peter A. Todd ${ }^{1, *}$ \\ ${ }^{1}$ Experimental Marine Ecology Laboratory, Department of Biological Sciences, National University of Singapore, \\ 14 Science Drive 4, Block S3, \#02-05, Singapore 117543 \\ ${ }^{2}$ Department of Spatial Ecology, Royal Netherlands Institute for Sea Research, Korringaweg 7, 4401 NT Yerseke, \\ The Netherlands
}

\begin{abstract}
As coastal cities around the world expand, and sea levels and the frequency of storms rise, natural shorelines are steadily being replaced by artificial defences such as seawalls. A growing number of studies have documented the assemblages that inhabit these novel environments, and some have contrasted them against those found in their natural analogues: rocky shores. Most of this work has, however, been conducted in temperate regions, and there is limited research on seawalls in the tropics. To address this, we conducted monthly surveys of adjacent seawall and rocky shores at multiple sites around Singapore for 1 yr. Our results concur with previous temperate studies - artificial seawalls support a lower diversity but share a substantial number of species with rocky shores. Multivariate analyses reveal that assemblage differences were largely driven by species that were found in both habitats (e.g. detritivore Ligia exotica, grazer Monodonta labio and carnivorous whelk Drupella margariticola) but occurred in different abundances. We also conducted (for the first time on seawalls) stable isotope analyses to elucidate the diets of the common species found in both habitats. Turf algae, which were found to be present in significantly lower abundances on seawalls, could possibly contribute substantially to the diets of many dominant herbivores. Future seawall enhancement efforts in the tropics could therefore look into whether enhancing turf algae will improve biodiversity.
\end{abstract}

KEY WORDS: Coastal urbanisation $\cdot$ Artificial structures $\cdot$ Community $\cdot$ Diet $\cdot$ Tropical

\section{INTRODUCTION}

With the rapid expansion and development of coastal cities, increasing sea levels and storm frequency, there has been a surge in the number and types of artificial structures being installed on urban shores worldwide (Airoldi et al. 2005, Chapman \& Underwood 2011). Many of them, including groynes, seawalls and breakwaters, serve protective functions, while others such as jetties and pontoons have industrial or recreational purposes (Thompson et al. 2002). The marine communities on these structures have been studied extensively and are represented

\footnotetext{
${ }^{*}$ Corresponding author: dbspat@nus.edu.sg
}

by a wide range of organisms. Assemblages can vary considerably, with some substrates being dominated by fouling species (Bacchiocchi \& Airoldi 2003, Qvarfordt et al. 2006) and others hosting assemblages not unlike those found on natural shores (Bulleri et al. 2005). The majority of studies, however, find that artificial structures are poor surrogates of natural habitats, often supporting less species diversity (Moschella et al. 2005, Gacia et al. 2007, Vaselli et al. 2008, Pister 2009, Ravinesh \& Bijukumar 2013), lower abundances (Connell 2001) or different assemblages entirely (Bulleri \& Chapman 2010, Megina et al. 2013).

() The authors 2018. Open Access under Creative Commons by Attribution Licence. Use, distribution and reproduction are unrestricted. Authors and original publication must be credited. 
Seawalls, in particular, have often been compared to natural rocky shores due to their structural similarities - both are hard-substrata, intertidal environments (Chapman \& Bulleri 2003, Moschella et al. 2005, Pister 2009, Ravinesh \& Bijukumar 2013, Aguilera et al. 2014). Even though compositionally different, seawalls and natural rocky shores often harbour similar suites of species; for example, in Sydney Harbour, Australia, Chapman \& Bulleri (2003) found that both habitats supported generally different assemblages at the high and mid-shore but that this was less apparent at the lower shore. In the tropical and sub-tropical habitats of Kerala, India (Ravinesh \& Bijukumar 2013) and Hong Kong (Lam et al. 2009), similar patterns were also observed - despite having a lower diversity than rocky shores, seawalls still supported a relatively large number of species that were shared with their natural analogues. By clearing patches of substrate in both habitats and monitoring the succession of species over time, Bulleri (2005) reported that assemblages were dissimilar even at the early stages of colonisation and that these trends persisted with time. Their study concluded that intrinsic differences between seawalls and rocky shores, such as topography, slope, texture and substrate, can all affect the recruitment of algae and invertebrates and consequently lead to fundamentally distinct assemblages.

Findings from comparative baseline studies are crucial to informing ecological engineering efforts to improve the diversity of the communities on these man-made structures. Currently, the bulk of seawall enhancement projects aim to either decrease the slope angle or manipulate the surface of the structure to provide more microhabitats (e.g. Chapman \& Underwood 2011, Firth et al. 2016, Loke et al. 2017). Steep or vertical seawalls condense the available area for organisms, which reduces the number of species due to the species-area relationship (Hawkins \& Hartnoll 1980) and increases the competition and other interactions among species living at different tidal heights (Bulleri \& Chapman 2010, Klein et al. 2011). Reducing the slope of the wall can counteract this, thereby improving species abundance and richness. Manipulation of the substrata can range from testing different materials (e.g. Burt et al. 2009, Ido \& Shimrit 2015) to increasing structural complexity, for example by incorporating and recreating natural shore elements such as rock pools, pits and grooves that act as refugia for intertidal species from biotic and abiotic stresses (Chapman \& Blockley 2009, Browne \& Chapman 2011, 2014, Loke et al. 2015, 2016, 2017.
Evans et al. 2016, Firth et al. 2016, Loke \& Todd 2016).

Despite the well-documented assemblage differences between seawalls and rocky shores in temperate zones, much less is known about how such communities in tropical climates are structured or what processes might be driving the differences. Given the rate that seawalls are replacing natural habitats in rapidly expanding tropical cities such as Singapore, Mumbai, Macau and Hong Kong (Glaser et al. 1991, Luo 1997, Murthy et al. 2001, Lai et al. 2015), there is a pressing need to gather this information so that appropriate management strategies can be devised. The island state of Singapore has built $319 \mathrm{~km}$ of sloping and vertical seawalls, covering $63 \%$ of its coastline (Lai et al. 2015). The few studies to date that have investigated the assemblages that inhabit these walls have revealed a relatively high diversity of intertidal organisms (Lee \& Sin 2009, Lee et al. 2009, Loke \& Todd 2016, Loke et al. 2016). For most of the islands south of the Singapore mainland, seawalls have almost completely replaced rocky shores and intertidal reefs. Nevertheless, there are still small stretches of natural shores remaining, often adjacent to the artificial defences, which provide an opportunity for a direct comparison of assemblages between seawalls and rocky shores that face similar environmental conditions and opportunities for larval recruitment. A deeper understanding of the processes that structure these communities will help tailor seawall enhancement efforts to the tropical context and alleviate the impacts of shoreline hardening (Gittman et al. 2015).

In addition to traditional biodiversity surveys, stable isotope analyses of assemblages (Fry 2008) can provide complementary data to help identify possible processes influencing community structure. Stable isotope analyses have been used extensively in temperate coastal systems to investigate trophic relationships (Dauby et al. 1998, Schaal et al. 2010), nutrient inputs (Machás \& Santos 1999) and human impacts (McClelland et al. 1997). Natural isotopic ratios of carbon and nitrogen in organisms provide information relating to their trophic level relative to each other and possible dietary constituents (Phillips \& Gregg 2003, Layman et al. 2012), which in turn can help reveal species interactions within a system.

Here, we compare the assemblage composition of neighbouring rocky shores and seawalls in Singapore and identify the key species driving assemblage differences. We use stable isotope analysis to attempt to elucidate the diets of the common species, and this represents the first attempt to do so in a tropical intertidal environment. 


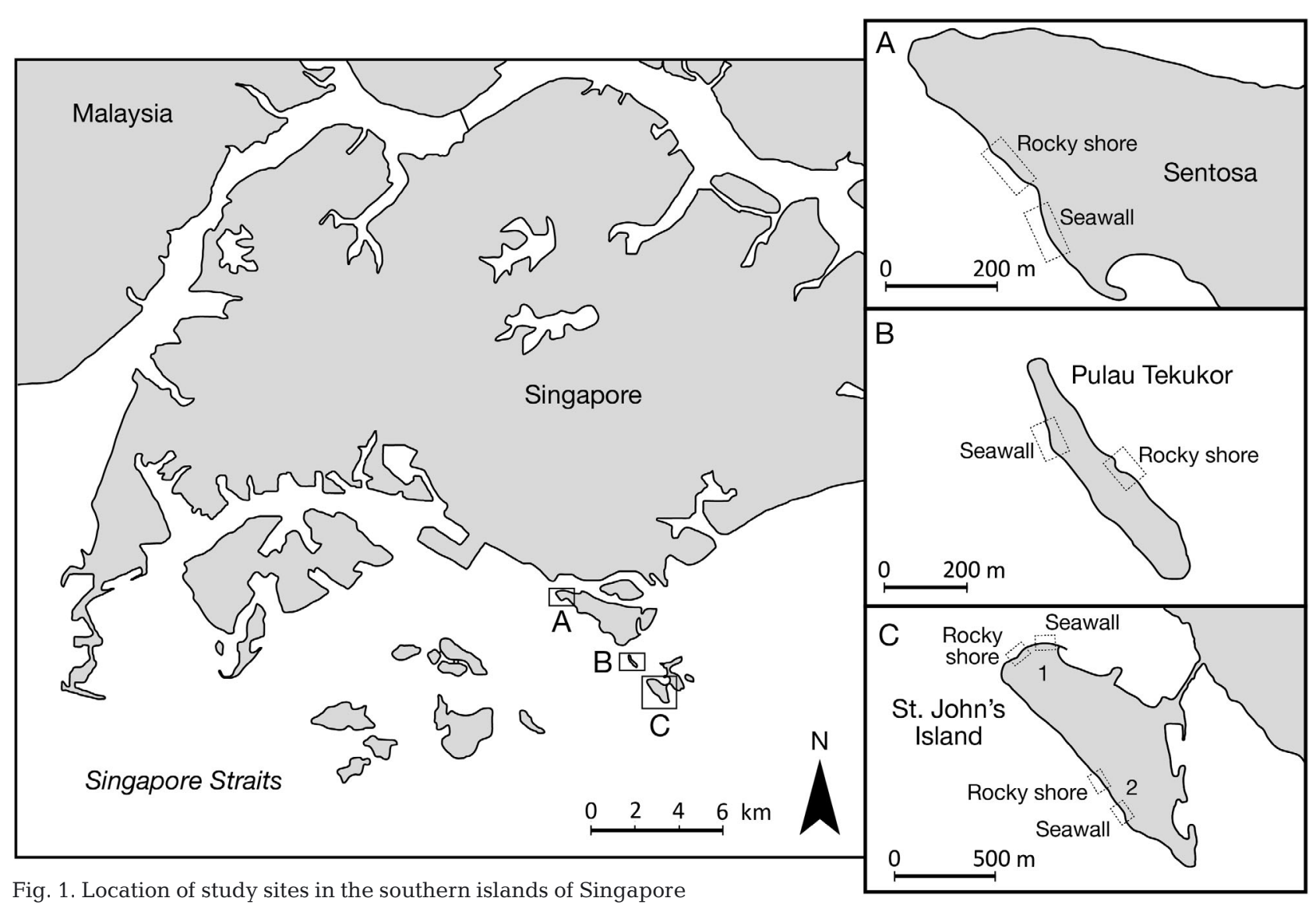

\section{MATERIALS AND METHODS}

\section{Study sites and survey methodology}

Singapore is a tropical island city-state that has modified over $80 \%$ of its coastline (Lai et al. 2015). Natural rocky shores are now limited to a short $300 \mathrm{~m}$ stretch along the southern shore (Todd \& Chou 2005) and several islands south of the mainland. The surveys were conducted at 4 sites on 3 of these southern islands (Fig. 1) - Pulau Tekukor (1² $13^{\prime} 50^{\prime \prime} \mathrm{N}, 103^{\circ}$

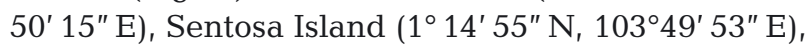
St. John's Island $1\left(1^{\circ} 13^{\prime} 24^{\prime \prime} \mathrm{N}, 103^{\circ} 50^{\prime} 40^{\prime \prime} \mathrm{E}\right)$ and St. John's Island 2 ( $\left.1^{\circ} 12^{\prime} 58^{\prime \prime} \mathrm{N}, 103^{\circ} 50^{\prime} 55^{\prime \prime} \mathrm{E}\right)$. Each site was selected such that rocky shore and seawall habitats were within close proximity of each other (<200 m apart). At each site, permanent belt transects parallel to shore were marked out at both habitats so that the same area could be sampled every month. The lengths of the belt transects were either 50 or $80 \mathrm{~m}$, and the vertical extent was from chart datum to mean water level (1.8 $\mathrm{m}$ above chart datum).

The surveys were conducted monthly during low spring tides over a period of 1 yr (from November
2011 to October 2012). Each month, six $50 \times 50 \mathrm{~cm}$ quadrats were placed randomly within the belt, resulting in 576 quadrats sampled (i.e. 4 sites $\times 2$ habitats $\times 12$ mo $\times 6$ quadrats). Photographs of each quadrat were taken and were later analysed for percentage cover of common algal functional groups or conspicuous taxa (e.g. turf algae, encrusting crustose algae, Sargassum spp., Padina spp.; Loke et al. 2016). These estimations were calculated from 30 randomly assigned points via the software Coral Point Count with Excel extensions (Kohler \& Gill 2006). The quadrats were also vacuumed with a modified Makita petrol-powered vacuum/blower (BHXV2500) for $1 \mathrm{~min}$ to catch highly mobile organisms, followed by hand collection of any remaining fauna for 2 min or until exhaustion (whichever occurred first). All samples were brought back to the laboratory, where living specimens were frozen at $-20^{\circ} \mathrm{C}$ until they were sorted, identified and quantified. All individuals were identified to the species or morphospecies level (species that are sufficiently morphologically different to be regarded as separate species; see Beattle \& Oliver 1994). 


\section{Stable isotope analyses}

Due to the large number of species observed throughout the year-long sampling period, only species/taxa that were common (encountered every month) were included in the stable isotope analyses. Algae species within the turf algal matrix could not be separated for individual analysis due to the small size of the individual filaments and were thus pooled together and treated as a single functional group. Twenty-six of the most common taxa across the entire survey were chosen for analysis - comprising 6 primary sources, 16 molluscs and 4 crustaceans. Specimens of these species were selected randomly from both habitats across the year for the stable isotope analysis. Suspended particulate matter (SPM) samples (that would include plankton and detrital matter) were obtained by filtering two 51 surface water samples through a GF/F $0.7 \mu \mathrm{m}$ glass fibre filter. Water was sampled at a low (albeit rising) tide, and although filter feeders might not be feeding at low tide, Gin et al. (2000) noted that the water column in the Singapore Straits is well mixed throughout the year; hence, we assumed that the SPM collected was representative of that within the water column.

Gastropods and bivalves were dissected to remove their shells before treatment, while whole organisms were used for all the other taxa, including crustaceans, as they were small $(<3 \mathrm{~cm}$ in length). The samples were soaked in $10 \% \mathrm{HCl}$ to remove carbonates, then rinsed with deionised water and dried at $60^{\circ} \mathrm{C}$ for $48 \mathrm{~h}$. If the organism size was very small (i.e. $<1 \mathrm{~cm}$ ), several individuals of the same species (and from the same site) would be pooled and analysed as a single sample. SPM samples were suction filtered, rinsed with $10 \% \mathrm{HCl}$ (to remove any calcium carbonate) followed by deionised water and then dried at $60^{\circ} \mathrm{C}$ for $24 \mathrm{~h}$ (Kwak \& Zedler 1997). All the dried samples were then ground to a fine powder and analysed for stable isotope compositions of carbon $\left(\delta^{13} \mathrm{C}\right)$ and nitrogen $\left(\delta^{15} \mathrm{~N}\right)$ using a PDZ Europa ANCA-GSL elemental analyser interfaced to a PDZ Europa 20-20 isotope ratio mass spectrometer (Sercon) at the University of California, Davis Stable Isotope Facility. Isotopic compositions obtained from ratios of ${ }^{13} \mathrm{C} /{ }^{12} \mathrm{C}$ and ${ }^{15} \mathrm{~N} /{ }^{14} \mathrm{~N}$ are relative to the international standards (Vienna Pee Dee Belemnite for carbon; atmospheric nitrogen for nitrogen).

Diets of the different organisms were also estimated using the IsoSource mixing model (Phillips \& Gregg 2003). Since none of the organisms could be reasonably assumed to consume a single food source, a combination of diets/food sources was assumed for all. The mixing model was used to give a range of proportional diet contributions from several identified main sources. The IsoSource model analysed diet contributions to a maximum of 6 sources due to computing constraints. The 6 primary consumer sources selected as potential food sources for carnivorous whelks were based on information from a past study by Chim \& Ong (2012). The model examined all potential diet combinations using source increments of $1 \%$ and accepted combinations within a mass balance tolerance of $0.1 \%$ (Phillips \& Gregg 2003). The isotopic signatures of each consumer were corrected to account for the enrichment during digestion and assimilation. These were taken to be $0.8 \%$ for $\delta^{13} \mathrm{C}$ and $1.5 \%$ for $\delta^{15} \mathrm{~N}$, based on past food web studies (France \& Peters 1997, Vanderklift \& Ponsard 2003, Bode et al. 2006).

\section{Statistical analyses}

The biodiversity survey data were standardised (Clarke \& Gorley 2006) to accommodate the different sampling units used for fauna (count) and algae (percent cover) and then square root transformed to down-weight the effects of the common species which might otherwise mask the influence of rarer species (Clarke 1993). A resemblance matrix of similarities was calculated using the Bray-Curtis index of similarity, and a permutational multivariate analysis of variance (PERMANOVA; Anderson 2001) was used to compare the assemblages using a factorial design with 3 factors: site (4 levels, random), habitat (2 levels, fixed) and month (12 levels, random) $(n=6)$. p-values were based on 9999 permutations. Additional pairwise comparisons of habitats within sites were made when interactions between the factors were significant. SIMPER analysis was also used to identify the percentage contribution that each species made to the measures of dissimilarity among assemblages to elucidate the species causing the differences between habitats (Clarke 1993). SIMPER and PERMANOVA analyses were conducted in PRIMER v7 (Clarke \& Gorley 2015).

Percent cover of all the common algal groups were compared, where possible, with a 3-way ANOVA (Habitat $\times$ Site $\times$ Month) using the GAD package in $\mathrm{R}$ v3.2.3 (R Core Team 2013). Prior to using ANOVA, Cochran's test (Winer 1971) was used to test for heterogeneity of variance, and where data did not fulfil this requirement, generalised linear mixed models (GLMM) were applied instead. All GLMMs were fit- 
ted to binomial distribution with the logit link function as data were recorded as proportions and were used to test for the effect of habitat (fixed factor) on algae cover, with site and month as random factors. Model selection was based on Akaike's information criterion.

\section{RESULTS}

\section{Assemblage differences}

A total of 167 faunal species/morphospecies (hereafter species) were identified from the 8297 individuals of fauna collected from 576 quadrats across the year, with crustaceans (39 species) and molluscs (92 species) being the dominant groups. A total of 138 species were found on rocky shores, and 105 were found on seawalls. Of these, 29 were found exclusively on seawalls, while 62 were only found on rocky shores. However, these species were generally rare, with only 6 having more than 10 individuals collected throughout the year-long survey.

The PERMANOVA (Table 1) showed that assemblages were significantly different among sites, between habitats and among months. There were also significant interactions between habitat and site, site and month, and month, site and habitat. The same patterns were revealed when the same analysis was performed on data with just presence and absence of species, indicating that differences were driven by the assemblage composition rather than the differences in abundances/cover of species (Table S1 in the Supplement at www.int-res.com/ articles/suppl/m587p041_supp.pdf). Pairwise comparisons between habitats within each site per month did not reveal any temporal trends across the year, although rocky shores and seawall assemblages overall differed significantly across all 4 sites (Table 2).

From the SIMPER analysis, average dissimilarity between the 2 habitats was 80.3 , with the top 3 species contributing most to the assemblage differences being turf algae (17.7\%), Ligia exotica (12.1\%) and Pictocolumbella ocellata (4.6\%) (Table S2 in the Supplement). None of the species that contributed cumulatively to more than $70 \%$ of the dissimilarity were found exclusively in either habitat, indicating that the differences in assemblages were mostly due to the differences in abundance of common species.

Species richness was significantly different among sites $\left(F_{3,480}=11.57, \mathrm{p}<0.01\right)$, between habitats $\left(F_{1,480}\right.$ $=7.00 . \mathrm{p}=0.01)$ and across months $\left(F_{11,480}=4.62, \mathrm{p}<\right.$
Table 1. Three-way permutational multivariate analysis of variance results for the analyses of differences between sites (random, 4 levels), habitats (fixed, 2 levels) and months (random, 12 levels) on square root transformed and standardised data consisting of abundances of organisms and algae percent cover

\begin{tabular}{|lrrcc|}
\hline & df & MS & Pseudo-F & p (perm) \\
\hline Site (S) & 3 & 19161 & 5.93 & $<0.001$ \\
Habitat (H) & 1 & 89213 & 4.02 & $<0.001$ \\
Month (M) & 11 & 6317 & 1.96 & $<0.001$ \\
$\mathrm{~S} \times \mathrm{H}$ & 3 & 19092 & 5.77 & $<0.001$ \\
$\mathrm{~S} \times \mathrm{M}$ & 33 & 3230 & 1.35 & $<0.001$ \\
$\mathrm{H} \times \mathrm{M}$ & 11 & 3903 & 1.18 & 0.17 \\
$\mathrm{~S} \times \mathrm{H} \times \mathrm{M}$ & 33 & 3310 & 1.38 & $<0.001$ \\
Residual & 480 & 2393 & & \\
Total & 575 & & & \\
\hline
\end{tabular}

Table 2. Results of the pairwise comparisons between the 2 habitats within each site per month. Results of the pairwise comparisons between the 2 habitats within each site across all months are in bold at the bottom of the table. ${ }^{*} \mathrm{p}<0.05,{ }^{* *} \mathrm{p}<0.01,{ }^{* * *} \mathrm{p}<0.001$

\begin{tabular}{|ccccc|}
\hline Month & $\begin{array}{c}\text { Pulau } \\
\text { Tekukor }\end{array}$ & Sentosa & $\begin{array}{c}\text { St. John's } \\
\text { Island 1 }\end{array}$ & $\begin{array}{c}\text { St. John's } \\
\text { Island 2 }\end{array}$ \\
\hline 1 & 0.07 & $<0.001^{* * *}$ & 0.21 & $<0.001^{* * *}$ \\
2 & 0.07 & $0.01^{* *}$ & $0.02^{*}$ & $<0.001^{* * *}$ \\
3 & $<0.001^{* * *}$ & $0.01^{* *}$ & $<0.001^{* * *}$ & 0.07 \\
4 & 0.09 & $<0.001^{* * *}$ & 0.60 & $<0.001^{* * *}$ \\
5 & 0.26 & $<0.001^{* * *}$ & 0.14 & $<0.001^{* * *}$ \\
6 & 0.07 & 0.36 & 0.08 & $0.52^{*}$ \\
7 & $0.05^{*}$ & $0.02^{*}$ & 0.39 & $0.03^{*}$ \\
8 & 0.18 & $<0.001^{* * *}$ & 1.00 & 0.23 \\
9 & 0.43 & $0.03^{*}$ & 0.50 & $0.01^{* *}$ \\
10 & $<0.001^{* * *}$ & $0.04^{* *}$ & 0.37 & 0.09 \\
11 & $0.01^{* *}$ & $0.01^{* *}$ & 0.69 & $<0.001^{* * *}$ \\
12 & $0.01^{* *}$ & 0.22 & 0.71 & $<0.001^{* * *}$ \\
& $<\mathbf{0 . 0 0 1}^{* * *}$ & $<\mathbf{0 . 0 0 1}^{* * *}$ & $\mathbf{0 . 0 5}^{*}$ & $<\mathbf{0 . 0 0 1}^{* * *}$ \\
\hline
\end{tabular}

0.01), with significant interactions between site and habitat $\left(F_{3,480}=16.51, \mathrm{p}<0.05\right)$, and site and month $\left(F_{33,480}=2.69, \mathrm{p}<0.01\right)$ (Table S3 in the Supplement). The greatest species richness was observed at Sentosa, with an average ( $\pm \mathrm{SE}$ ) of $4.6( \pm 0.5)$ species collected in each quadrat, followed by St. John's Island 1 (4.3 \pm 0.5$)$, St. John's Island $2(3.4 \pm 0.3)$ and Pulau Tekukor $(3.1 \pm 0.4)$. Faunal species richness was significantly lower across all seawalls, with rocky shores supporting an average $( \pm \mathrm{SE})$ of $4.1( \pm 0.1)$ species per quadrat, as opposed to $3.5( \pm 0.1)$ on seawalls.

Overall macroalgae cover was significantly higher on rocky shores (33.9\% on rocky shores vs. $21.4 \%$ on seawalls; $F_{1,480}=30.14, \mathrm{p}<0.001$, Table S4 in the Supplement) and was significantly different across 
sites $\left(F_{3,480}=22.70, \mathrm{p}<0.01\right.$, Table S4), with no significant interactions among factors. Macroalgae cover (mean $\pm \mathrm{SE}$ ) across sites followed a similar pattern to faunal richness, with the highest observed at Sentosa $(38.6 \pm 5.5 \%)$, followed by St. John's Island 2 (34.3 $\pm 5.6 \%)$, St. John's Island 1 (19.5 $\pm 3.7 \%)$ and Pulau Tekukor $(17.2 \pm 3.7 \%)$. Of the functional macroalgal groups examined (Tables S5-S7 in the Supplement), only turf algae $\left(F_{1,480}=48.5, \mathrm{p}<\right.$ 0.001, Table S7) showed significant differences in cover between habitats, with rocky shores supporting a greater cover of turfs (25.2\% on rocky shores vs. $12.9 \%$ on seawalls). The cover of turf algae also showed significant differences across sites $\left(F_{3,480}=\right.$ 4.83, $\mathrm{p}<0.01$, Table S7 in the Supplement), with interactions between site and habitat. Padina sp. could not be analysed with either method due to very low relative cover, which averaged $<1.0 \%$ in both habitats.
Table 3. Stable isotope ratios $\delta^{13} \mathrm{C}(\%)$ and $\delta^{15} \mathrm{~N}(\%)$ of common sources (suspended particulate matter and algae) and consumers (crustaceans and molluscs) on rocky shores and seawalls. n/a: not applicable

\begin{tabular}{|llrcc|}
\hline & Type & $\mathrm{n}$ & $\delta^{13} \mathrm{C}$ & $\delta^{15} \mathrm{~N}$ \\
\hline Suspended particulate matter & n/a & 4 & $-27.7 \pm 2.6$ & $-2.9 \pm 1.8$ \\
Bryopsis sp. & Algae & 2 & $-19.2 \pm 0.7$ & $6.2 \pm 0.8$ \\
Encrusting crustose algae & Algae & 5 & $-12.4 \pm 2.9$ & $5.1 \pm 0.8$ \\
Padina sp. & Algae & 1 & -11.1 & 5.7 \\
Sargassum polycystum & Algae & 12 & $-17.7 \pm 1.7$ & $6.5 \pm 1.6$ \\
Turf algae & Algae & 6 & $-15.3 \pm 0.8$ & $7.1 \pm 0.7$ \\
Barbatia amygdalumtostum & Mollusc & 6 & $-16.8 \pm 1.0$ & $7.6 \pm 0.4$ \\
Cellana radiata & Mollusc & 4 & $-15.1 \pm 1.0$ & $6.6 \pm 0.7$ \\
Drupella margariticola & Mollusc & 10 & $-15.4 \pm 2.8$ & $8.7 \pm 2.2$ \\
Monodonta labio & Mollusc & 8 & $-14.3 \pm 2.7$ & $6.3 \pm 0.6$ \\
Morula fusca & Mollusc & 6 & $-13.7 \pm 1.6$ & $8.7 \pm 0.6$ \\
Morula musiva & Mollusc & 6 & $-16.0 \pm 1.1$ & $9.4 \pm 1.0$ \\
Nerita chamaeleon & Mollusc & 5 & $-12.56 \pm 1.9$ & $6.6 \pm 0.8$ \\
Nerita undata & Mollusc & 7 & $-13.4 \pm 2.0$ & $7.3 \pm 0.9$ \\
Pardalina testudinaria & Mollusc & 4 & $-16.5 \pm 1.8$ & $8.5 \pm 0.7$ \\
Patelloida saccharinoides & Mollusc & 3 & $-11.1 \pm 1.4$ & $6.4 \pm 0.9$ \\
Pictocolumbella ocellata & Mollusc & 16 & $-14.9 \pm 1.8$ & $7.7 \pm 0.8$ \\
Planaxis salcatus & Mollusc & 1 & -15.1 & 7.9 \\
Siphonaria guamensis & Mollusc & 5 & $-14.8 \pm 2.6$ & $6.7 \pm 1.4$ \\
Siphonaria javanica & Mollusc & 5 & $-11.6 \pm 1.4$ & $5.9 \pm 1.3$ \\
Trochus maculatus & Mollusc & 9 & $-15.1 \pm 1.8$ & $7.5 \pm 1.0$ \\
Turbo bruneus & Mollusc & 7 & $-15.1 \pm 0.8$ & $6.4 \pm 0.6$ \\
Balanus sp. & Crustacean & 3 & $-17.5 \pm 0.1$ & $10.2 \pm 0.0$ \\
Myomenippe hardwickii & Crustacean & 2 & $-17.2 \pm 0.3$ & $7.0 \pm 0.8$ \\
Ligia exotica & Crustacean & 7 & $-15.1 \pm 0.6$ & $4.8 \pm 2.3$ \\
Tetraclita sp. & Crustacean & 3 & $-17.5 \pm 0.3$ & $10.6 \pm 0.2$ \\
\hline & & & & \\
\hline
\end{tabular}

\section{$\delta^{13} \mathrm{C}$ and $\delta^{15} \mathrm{~N}$ of common species}

The isotopic values of the common sources and consumers on rocky shores and seawalls showed a high degree of variability within each taxon (Table 3). The carnivorous whelk Drupella margariticola had the largest standard deviations among all organisms tested. Similar to previous studies (Kwak \& Zedler 1997, Grall et al. 2006), the SPM had the lowest isotopic value for both isotopes, with a $\delta^{13} \mathrm{C}$ value of $-27.7 \%$ and $\delta^{15} \mathrm{~N}$ of $-2.9 \%$. The algae sources had higher but similar isotopic values, with Bryoposis sp. and Sargassum sp. the most ${ }^{13} \mathrm{C}$ depleted (-19.2 and $-17.7 \%$, respectively), turf algae less so (15.3\%) and Padina sp. and encrusting crustose algae the least $(-11.1$ and $-12.4 \%$, respectively). With the exception of Siphonaria javanica and Patelloida saccharinoides, most of the isotopic signatures of the primary consumers (when adjusted for fractionation) fell within the mixing polygon boundaries of these 6 sources, indicating that the sources were probable contributors to their diets (Fig. 2).

The overlapping ranges of $\delta^{15} \mathrm{~N}$ led to poor separation between the trophic levels of the primary pro- ducers and the primary consumers (known herbivores such as Nerita sp., Trochus maculatus, Turbo bruneus and limpets Siphonaria sp. and P. saccharinoides) (Fig. 3A). Barbatia amygdalumtostum, a filter-feeding bivalve, as well as crab Myomenippe hardwickii (juveniles) were also found within this range. The trophic separation of the secondary consumers (carnivorous whelks) was more distinct (Fig. 3B), with a $\delta^{15} \mathrm{~N}$ range of 8.7 to $9.4 \%$. The detritivorous isopod L. exotica was on the extreme end, with the lowest $\left(4.8 \%\right.$ ) $\delta^{15} \mathrm{~N}$ values. Barnacles Tetraclita sp. and Balanus sp. had the highest mean $\delta^{15} \mathrm{~N}$, with a range of 10.2 to $10.6 \%$ (Fig. 3C).

The IsoSource analyses for the primary consumers based on the 6 sources ( 5 algae and SPM) showed a wide range of feasible solutions, which can happen when consumers' isotopic signatures fall near the centre of the mixing polygon (Phillips \& Gregg 2003), making it difficult to resolve a strongly determined and unique solution (Fry 2013). While a posteriori aggregation was considered to reduce the number of sources and subsequently the range of solutions (Phillips et al. 2005), this alternative was eventually abandoned, as there was no clear relation between 
Fig. 2. Bi-plot of stable isotope ratios $\delta^{13} \mathrm{C}$ and $\delta^{15} \mathrm{~N}$ (mean $\pm \mathrm{SE}$ ) for consumers within the mixing polygon of potential food sources. Suspended particulate matter (SPM) is connected by the grey dotted lines but is not featured due to its extreme negative values $\left(\delta^{13} \mathrm{C}=-27.7, \delta^{15} \mathrm{~N}=\right.$ $-2.9)$. Trophic shifts between food sources and consumers of 0.8 and 1.5 for $\delta^{13} \mathrm{C}$ and $\delta^{15} \mathrm{~N}$, respectively, were applied

the sources with close isotopic signatures to justify the aggregation (i.e. Sargassum sp. and Bryopsis sp.; Padina sp. and encrusting crustose algae). As such, mean, $1^{\text {st }}$ and $99^{\text {th }}$ percentiles of possible values of each source were reported (Table 4).

The similar isotopic values between Bryoposis sp. and Sargassum sp., and Padina sp. and encrusting crustose algae led to similar diet contribution solutions within each pair. Our results showed that turf algae, Padina sp. and encrusting crustose algae were potentially important contributors to the diets of several herbivorous species. Turf algae likely contributed to the diet of Pictocollumbella ocellata (a species which contributed substantially to between-habitat differences), whose 1st percentile values were more than zero. Turf algae also had high possible contributions for Planaxis sulcatus $\left(99^{\text {th }}\right.$ percentile $\left.=81 \%\right)$ and $T$. maculatus (69\%). Padina sp. and encrusting crustose algae also had relatively high possible contributions to the diets of several species, including L. exotica (69 to $75 \%$ ), Monodonta labio (59 to 65\%) and Nerita chamaeleon (78 to $85 \%$ ). Diet contributions for limpets $S$. javanica and $P$. saccharinoides were not able to be resolved, as their isotopic values fell outside those of the 6 sources.

The diets of the predatory whelks $D$. margariticola, Morula fusca and M. musiva were based on 6 sources consisting of grazing gastropods T. bruneus, Sipho-

Fig. 3. Nitrogen stable isotope ratio $\delta^{15} \mathrm{~N}$ (mean $\pm \mathrm{SE}$ ) (\%) for potential food sources (suspended particulate matter not featured; $\delta^{15} \mathrm{~N}=-3.0$ ) and consumers. Boxes delineate (A) algae and primary consumers, (B) secondary consumers and $(\mathrm{C})$ barnacles
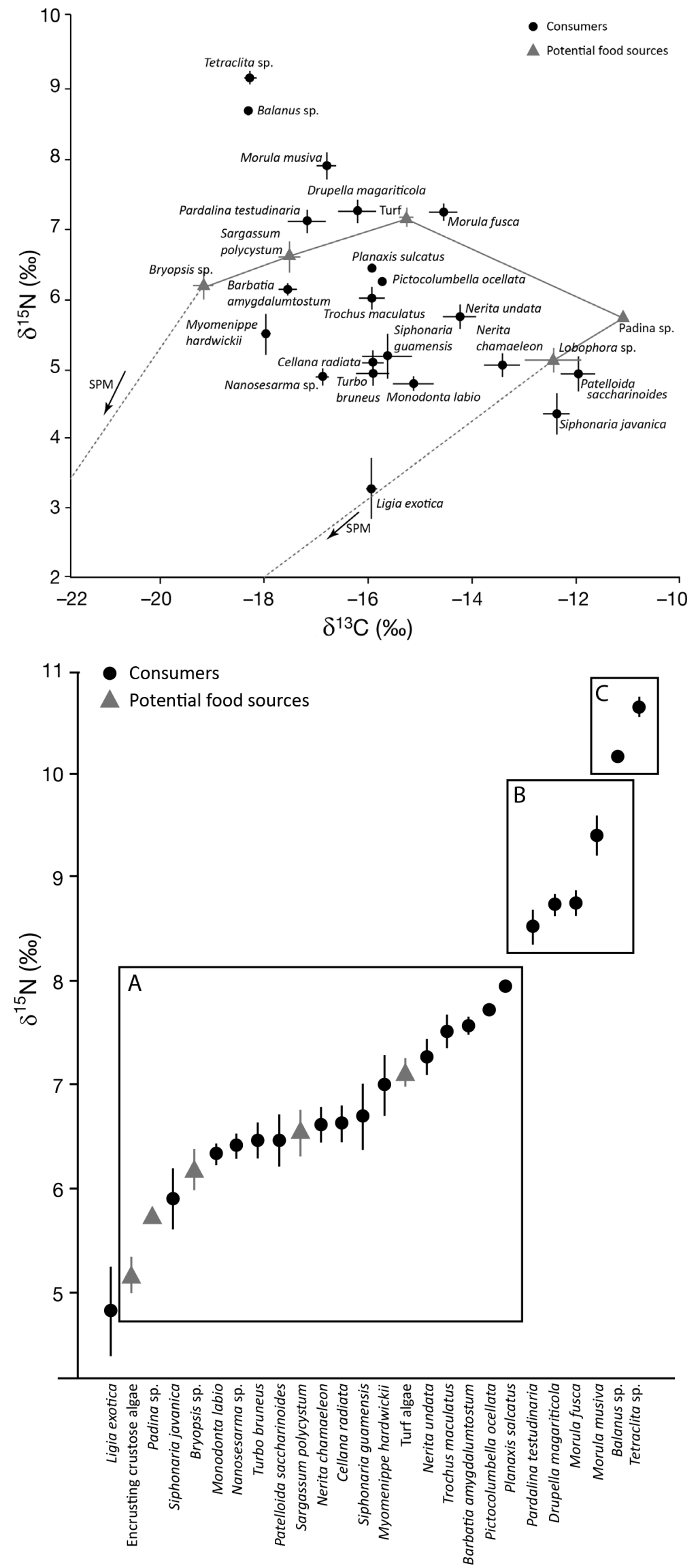
Table 4. IsoSource mixing model estimates of the contribution (\%) of 6 different sources to the diets of primary consumers. Means presented with 1 and $99 \%$ confidence limits in parentheses

\begin{tabular}{|lcccrcr|}
\hline Species & $\begin{array}{c}\text { Bryopsis } \\
\text { sp. }\end{array}$ & $\begin{array}{c}\text { Sargassum } \\
\text { sp. }\end{array}$ & $\begin{array}{c}\text { Turf } \\
\text { algae }\end{array}$ & $\begin{array}{c}\text { Padina } \\
\text { sp. }\end{array}$ & $\begin{array}{c}\text { Encrusting } \\
\text { crustose } \\
\text { algae }\end{array}$ & $\begin{array}{c}\text { Suspended } \\
\text { particulate } \\
\text { matter }\end{array}$ \\
& & & & & \\
Cellana radiata & $14(0-37)$ & $15(0-40)$ & $16(0-48)$ & $21(0-46)$ & $23(0-51)$ & $10(6-14)$ \\
Barbatia amygdalumtostum & $41(1-76)$ & $31(0-82)$ & $15(0-45)$ & $5(0-16)$ & $5(0-17)$ & $3(0-7)$ \\
Ligia exotica & $1(0-4)$ & $31(0-75)$ & $1(0-5)$ & $40(1-69)$ & $31(0-75)$ & $26(0-28)$ \\
Monodonta labio & $9(0-6)$ & $9(0-8)$ & $11(0-31)$ & $29(0-59)$ & $31(0-65)$ & $11(8-15)$ \\
Myomenippe hardwickii & $34(0-68)$ & $28(0-73)$ & $16(0-51)$ & $5(0-18)$ & $6(0-20)$ & $9(5-13)$ \\
Nerita chamaeleon & $4(0-12)$ & $4(0-13)$ & $5(0-15)$ & $41(0-78)$ & $40(0-85)$ & $6(0-9)$ \\
Nerita undata & $11(0-32)$ & $13(0-36)$ & $16(0-15)$ & $30(0-58)$ & $27(0-59)$ & $2(8-6)$ \\
Pictocolumbella ocellata & $15(0-42)$ & $24(0-62)$ & $33(2-74)$ & $15(0-33)$ & $12(0-29)$ & $2(0-6)$ \\
Planaxis sulcatus & $15(0-38)$ & $23(0-62)$ & $42(0-81)$ & $10(0-24)$ & $8(0-22)$ & $2(1-6)$ \\
Siphonaria guamensis & $13(0-36)$ & $24(0-53)$ & $16(0-46)$ & $23(0-48)$ & $25(0-53)$ & $9(5-13)$ \\
Trochus maculatus & $20(0-51)$ & $23(0-61)$ & $24(0-69)$ & $14(0-35)$ & $14(0-35)$ & $3(0-8)$ \\
Turbo bruneus & $13(0-34)$ & $13(0-37)$ & $15(0-44)$ & $22(0-47)$ & $24(0-52)$ & $12(8-16)$ \\
\hline
\end{tabular}

naria guamensis, S. javanica and Nerita undata; barnacle Balanus sp.; and bivalve $B$. amygdalumtostum (Table 5), and the diets of $D$. margariticola and $M$. musiva were relatively well constrained, with $B$. amygdalumtostum contributing the majority of the diet for D. margariticola (mean $=67 \%$ ) and $M$. musiva (75\%). M. fusca had less well constrained possible diet contributions, making it difficult to draw similar conclusions.

\section{DISCUSSION}

The results of the year-long survey indicate that seawall assemblages are different from those of natural rocky shores in Singapore, concurring with previous (mostly temperate) studies (e.g. Chapman \& Bulleri 2003, Bulleri et al. 2005, Moschella et al. 2005, Pister 2009, Aguilera et al. 2014). There was, however, also a substantial (45\%) overlap between the taxa in both habitats, suggesting that seawalls can support a similar suite of species to their natural analogues. Significantly greater cover of turf algae was found on rocky shores and is possibly a dominant contributor to the diets of the primary consumers.
The isopod Ligia exotica, which was the faunal species that contributed most to the assemblage differences between the habitats and was closely associated with seawalls, had a very low $\delta^{15} \mathrm{~N}$ value, characteristic of a detritivore that is less dependent on the primary production of a system.

\section{Key site and habitat differences}

Assemblages surveyed were significantly different among sites, between habitats and among months, with significant interactions between the 3 factors. However, when pairwise comparisons between habitats (the only fixed factor) were made, no distinct temporal patterns of assemblage differences between rocky shore and seawall habitats were apparent. Across the $12 \mathrm{mo}$, assemblages between the 2 habitats were significantly different in at least one of the sites except for month 6. The 3-way ANOVA for faunal species richness did show that there were significant differences between months. Our analyses on several algal groups revealed that time did not have a significant effect on percent cover of algae. This lack of temporal patterns in the assemblage is

Table 5. IsoSource mixing model estimates of the contribution (\%) of 6 different sources to the diets of secondary consumers. Means presented with 1 and $99 \%$ confidence limits in parentheses

\begin{tabular}{|c|c|c|c|c|c|c|}
\hline Species & Balanus sp. & $\begin{array}{l}\text { Turbo } \\
\text { bruneus }\end{array}$ & $\begin{array}{l}\text { Siphonaria } \\
\text { guamensis }\end{array}$ & S. javanica & $\begin{array}{l}\text { Nerita } \\
\text { undata }\end{array}$ & $\begin{array}{c}\text { Barbatia } \\
\text { amygdalumtostum }\end{array}$ \\
\hline Drupella margariticola & $2(0-7)$ & $18(0-38)$ & $9(0-29)$ & $2(0-9)$ & $2(0-8)$ & $67(52-80)$ \\
\hline Morula musiva & $17(11-22)$ & $4(0-14)$ & $3(0-11)$ & $1(0-4)$ & $1(0-5)$ & $75(63-85)$ \\
\hline Morula fusca & $13(1-25)$ & $13(0-37)$ & $16(0-48)$ & $18(0-41)$ & $26(0-58)$ & $13(0-35)$ \\
\hline
\end{tabular}


markedly different from the seasonality that is often observed on temperate and sub-tropical shores (Underwood 1981, Williams 1993).

Among the 4 sites, Sentosa supported the greatest species richness, followed by St. John's Island 2, St. John's Island 1 and then Pulau Tekukor. The same pattern among sites was also observed for macroalgal cover, suggesting that the abundance of macroalgae at a site and its faunal species richness could be linked. Given that all 4 sites were found within the Singapore Strait (the largest distance between sites being just over $7 \mathrm{~km}$ ), we suggest that the assemblage patterns observed were more likely due to the inherent nature of the sites (e.g. slope, micro-environment) rather than availability of larval sources.

All the rocky shores surveyed had significantly greater macroalgal cover, and supported a richer faunal species diversity, compared to their artificial analogues. The PERMANOVA showed that the assemblages between rocky shores and seawalls were distinct. Common taxa, such as turf algae, isopod L. exotica and gastropod Pictocolumbella ocellata, contributed the most towards these dissimilarities. It is important to note that these, and other species which made up more than $70 \%$ of the dissimilarities between habitats, were dominant taxa present in both habitats. Of the 167 species/morphospecies collected, only 91 were found exclusively in either habitat (most of these were generally rare). It is possible that both habitats have the potential to recruit and sustain a similar suite of species, but experimentation to study the actual recruitment and subsequent survival (e.g. Bulleri 2005) would be needed to verify this.

\section{Diet contributions based on stable isotope analyses}

Stable isotope analyses of the primary consumers from both habitats revealed a large range in $\delta^{15} \mathrm{~N}$ values and variation in $\delta^{13} \mathrm{C}$ values, indicating that there were overlapping food sources, and alludes to a complex food web - a common feature of a diverse system (Grall et al. 2006). The output from the IsoSource analyses had a relatively low resolution, leading to a wide range of possible solutions (Phillips \& Gregg 2003). Based on the feasible diet solutions from the model estimates, turf algae and encrusting crustose algae showed high potential diet contributions. Numerous past studies have found that turf algae are often grazed by herbivores of various sizes due to the small size of its filaments (Steneck \& Watling 1982, Boaventura et al. 2002), although there is less evi- dence that Padina spp. and encrusting algae are favoured. While encrusting crustose algae could also be an important food source for grazers, they occur in much lower densities and are likely a minor food source; the average difference in cover in encrusting crustose algae between rocky shores and seawalls is only $3 \%$, as opposed to $12.3 \%$ for turf algae. We suggest that the lower cover of turf algae on seawalls could lead to limitations on grazer populations, particularly in species which feed on turf algae, such as the gastropod Pictocollumbella ocellata, which was found to be associated with rocky shores. Bryopsis sp. and Sargassum sp. were found not to be dominant in the possible diets of most of the herbivores, with the exception of the bivalve Barbatia amygdalumtostum. This species was often encountered underneath, or attached to, rocks in the low intertidal zone (S. Lai pers. obs.), and it is reasonable to conclude that its position on the shore influences its feeding habit. Filter feeders located within the low intertidal zone are more likely to obtain their food from broken-down algal matter around them than those found higher up the shore (e.g. barnacles) (Steinarsdóttir et al. 2009). With Bryopsis sp. and Sargassum sp. being present in large quantities within the low shore, it is conceivable that they contributed substantially to the diets of $B$. amygdalumtostum through the broken-down organic material in the water column.

The diets of 2 species of limpets, Siphonaria javanica and Patelloida saccharinoides, could not be resolved, as their isotopic signatures fell outside the boundaries of the 6 primary sources used. Siphonariids and patelloids are known to be capable of feeding on a variety of food sources including biofilm, microalgae, epiphytes, cyanobacteria and diatoms and generally vary widely in their diets (Hawkins et al. 1989, Della-Santina et al. 1993, Thompson et al. 2004, Bano et al. 2014). We propose that both species were feeding on sources not examined in this study, making it impossible to resolve their diet contributions.

The diet contributions in the secondary consumers were relatively well defined compared to the primary consumers, with $B$. amygdalumtostum constituting the majority of the diets of the whelks Drupella margariticola and Morula musiva. This shows a preference for sessile prey, which has been documented in other whelks found in the tropics (Taylor 1976). The diet composition of $M$. fusca was less defined, with contributions ranging from 13 to $26 \%$, which could result from $M$. fusca feeding on a variety of prey. While past research found that $M$. fusca preys primarily on pulmonate limpets (Siphonaria spp.), they also feed on many other taxa (Chim \& Ong 2012). Whelk 
species have also been known to feed on barnacles (Fairweather \& Underwood 1983, Fairweather et al. 1984), but it is clear from the diet compositions of the 3 carnivorous gastropods that barnacles do not constitute a major diet component. It is possible that the barnacles examined in this study are found too high up the shore to be commonly encountered by the gastropods.

The trophic positioning based on $\delta^{15} \mathrm{~N}$ values also revealed dietary clues, particularly for the species on the extreme ends of the spectrum. L. exotica had the lowest $\delta^{15} \mathrm{~N}$ value of all the consumers examined. Isopods from the genus Ligia are known to be scavengers or detritivores that feed on algal debris (Koop \& Field 1980, Pennings et al. 2000, Laurand \& Riera 2006), and the results of the present study support this. The bulk of the diet of $L$. exotica came from the alga Padina sp., encrusting crustose algae and Sargassum sp. but was generally more $\delta^{15} \mathrm{~N}$ depleted than the other primary consumers. This could indicate that $L$. exotica fed on more decayed algal matter (versus fresh matter), as consuming detritus generally leads to lower enrichment (Vanderklift \& Ponsard 2003). On the opposite end of the $\delta^{15} \mathrm{~N}$ scale, both barnacle species (Tetraclita sp. and Balanus sp.) had the greatest difference in $\delta^{15} \mathrm{~N}$ values above those of the secondary consumers (3.36\% on average). This demonstrates that the barnacles are selectively feeding on more enriched organisms (e.g. polychaete needles and porifera needles) within the suspended matter of the water column, as described in past studies (Steinarsdóttir et al. 2009, Schaal et al. 2010).

While our results provide some indication regarding what the dominant organisms in both habitats could be feeding on in situ, it should be noted that our interpretation from stable isotopes and the resultant output from IsoSource have limitations. IsoSource calculates all the feasible diet contribution solutions from the mixing polygon and calculates the averages from a subsample. In cases where a unique solution is not possible and there are a range of potential solutions (as is the case in our study), it assumes that uncertainty in source contributions is divided evenly among sources (Fry 2013). Additionally, the reliability of the IsoSource output is dependent on that of the sources used. We recognise that water sampled at low tide may not be representative of the filter feeders' diets, which are more likely to feed at high tide. Future work using approaches such as gut content analysis (e.g. Notman et al. 2016) and feeding preference experiments (e.g. Underwood \& Clarke 2005) are needed to refine the interpretation of our current findings (Fry 2013) and allow a better un- derstanding of the trophic interactions occurring in these tropical shores.

\section{Algal limitation shaping seawall assemblages and implications for ecological engineering}

One potential explanation driving the observed assemblage differences between rocky shores and seawalls is the latter's lower levels of primary productivity. The lack of algal abundance (particularly turf algae) to support higher trophic levels and complex interactions may also lead to the proliferation of detritivores (L. exotica) which are dependent on allochthonous detrital sources (e.g. imported algae wracks). This phenomenon is absent on the rocky shore due to the higher abundance of algae, which is important in supporting a variety of primary consumers; this in turn leads to the higher abundances of higher trophic species such as D. margariticola and M. fusca. Our findings are an example of how urban structures create physical stressors that modify assemblages by interacting with top-down and bottom-up processes (Thompson et al. 2004). Seawalls create harsh conditions that some organisms which usually live on natural rocky shores have difficulty coping with (Chapman 2003). The steeper profile of the seawall means that a larger proportion of the wall is emersed during low tide and is prone to desiccation, particularly where the substrate is smooth and cannot retain water (Chapman \& Bulleri 2003, Bulleri \& Chapman 2010), as is typically the case when the defences are constructed of granite or concrete. The smaller area also leads to a more concentrated swash, increasing the wave impact and scour on the wall (Moschella et al. 2005). Given that desiccation and water motion can prevent successful recruitment and establishment in the early life stages of algae (Vadas et al. 1992), the steep slope of the seawalls could greatly diminish the primary productivity potential. It is vital that future experiments test whether engineering these artificial structures to alleviate or eliminate this limitation can improve the assemblage, leading to a greater number of natural rocky shore-associated species that have been displaced by seawalls. For example, Loke \& Todd (2016) found that complex tiles supported greater intertidal biodiversity on seawalls in Singapore compared to simple tiles and that assemblage differences were largely driven by the presence of $D$. margariticola that typified the natural shores.

Currently, a multitude of techniques to improve various physical factors of seawalls, for example topo- 
graphic complexity, slope angle, and elevation, have been attempted (Moreira et al. 2007, Chapman \& Blockley 2009, Chapman \& Underwood 2011, Firth et al. 2013, Browne \& Chapman 2014, Loke et al. 2015, Ido \& Shimrit 2015, Martins et al. 2016, Loke \& Todd 2016). Very few, however, have been targeted directly at recruiting a high abundance and diversity of native algal species (e.g. Perkol-Finkel \& Airoldi 2010, Ferrario et al. 2016). There have been some efforts in using algae to enhance coastal structures, although these have largely been aimed at transplanting canopy-forming algae, which in themselves produce a complex habitat that supports diverse communities in temperate regions (Perkol-Finkel et al. 2012). In Singapore, canopy-forming algae (e.g. Sargassum spp.) do not contribute to the inter-habitat differences as substantially as turf algae. As such, future research into the ecological engineering of tropical seawalls could consider testing whether enhancing turf algae (or productivity) can increase diversity and, if so, consider improving the recruitment and growth of turf algae. In Singapore, green turf algae are typically succeeded by more grazer-resistant erect and encrusting red/brown algae within the span of months (Loke et al. 2016); understanding these processes will help develop strategies to enhance biodiversity on existing artificial coastal defences. Potential solutions include encouraging turf algal growth via bioactive substrates as well as improving water retention further up the slope of the seawalls.

This study is the first to combine stable isotope analyses with traditional surveys to examine the assemblages of rocky shores and seawalls in the tropics. Our findings identify primary productivity on seawalls as a potential limiting factor causing the lower diversity we often observed. Further experimentation is needed to identify rigorously the diets of the key organisms in these novel habitats. A more thorough understanding of interactions among species can help guide future ecological engineering efforts towards the enhancement of intertidal diversity on artificial coastal structures.

Acknowledgements. This research was funded by Singapore's National Research Foundation (via MSRDP-P05) grant number R-154-000-566-490, NParks CME grant number R-154-000-566-490 and Singapore Delft Water Alliance (SDWA) JBE Part B grant number R-303-001-021-414. The authors thank NParks for providing permits for the surveys (NP/RP11-058) and Sentosa Development Corporation for facilitating access to the various field sites. We also thank the editor, Lisandro Benedetti-Cecchi; 3 anonymous reviewers; and Professor Stephen Hawkins for their constructive comments on the manuscript.

\section{LITERATURE CITED}

Aguilera MA, Broitman BR, Thiel M (2014) Spatial variability in community composition on a granite breakwater versus natural rocky shores: lack of microhabitats suppresses intertidal biodiversity. Mar Pollut Bull 87: $257-268$

Airoldi L, Abbiati M, Beck MW, Hawkins SJ and others (2005) An ecological perspective on the deployment and design of low-crested and other hard coastal defence structures. Coast Eng 52:1073-1087

Anderson MJ (2001) A new method for non-parametric multivariate analysis of variance. Austral Ecol 26:32-46

Bacchiocchi F, Airoldi L (2003) Distribution and dynamics of epibiota on hard structures for coastal protection. Estuar Coast Shelf Sci 56:1157-1166

Bano A, Ayub Z, Siddiqui G (2014) Fatty acid composition of three species of Siphonaria (Gastropoda: Pulmonata) in Pakistan. Pak J Zool 46:813-818

* Beattle AJ, Oliver I (1994) Taxonomic minimalism. Trends Ecol Evol 9:488-490

* Boaventura D, Alexander M, Della Santina P, Smith ND, Ré P, da Fonseca LC, Hawkins SJ (2002) The effects of grazing on the distribution and composition of low-shore algal communities on the central coast of Portugal and on the southern coast of Britain. J Exp Mar Biol Ecol 267:185-206

* Bode A, Alvarez-Ossorio MT, Varela M (2006) Phytoplankton and macrophyte contributions to littoral food webs in the Galician upwelling estimated from stable isotopes. Mar Ecol Prog Ser 318:89-102

*Bowne MA, Chapman MG (2011) Ecologically informed engineering reduces loss of intertidal biodiversity on artificial shorelines. Environ Sci Technol 45:8204-8207

*Bowne MA, Chapman MG (2014) Mitigating against the loss of species by adding artificial intertidal pools to existing seawalls. Mar Ecol Prog Ser 497:119-129

Bulleri F (2005) Role of recruitment in causing differences between intertidal assemblages on seawalls and rocky shores. Mar Ecol Prog Ser 287:53-65

*Bulleri F, Chapman MG, Underwood AJ (2005) Intertidal assemblages on seawalls and vertical rocky shores in Sydney Harbour, Australia. Austral Ecol 30:655-667

* Bulleri F, Chapman M (2010) The introduction of coastal infrastructure as a driver of change in marine environments. J Appl Ecol 47:26-35

* Burt J, Bartholomew A, Bauman A, Saif A, Sale PF (2009) Coral recruitment and early benthic community development on several materials used in the construction of artificial reefs and breakwaters. J Exp Mar Biol Ecol 373: $72-78$

* Chapman MG (2003) Paucity of mobile species on constructed seawalls: effects of urbanization on biodiversity. Mar Ecol Prog Ser 264:21-29

Chapman MG, Blockley DJ (2009) Engineering novel habitats on urban infrastructure to increase intertidal biodiversity. Oecologia 161:625-635

Chapman MG, Bulleri F (2003) Intertidal seawalls - new features of landscape in intertidal environments. Landsc Urban Plan 62:159-172

* Chapman MG, Underwood AJ (2011) Evaluation of ecological engineering of 'armoured' shorelines to improve their value as habitat. J Exp Mar Biol Ecol 400:302-313

Chim CK, Ong YYB (2012) Diet of an intertidal predator, Morula fusca (Neogastropoda: Muricidae) on St. John's Island, Singapore. Contrib Mar Sci 2012:153-158 
Clarke RK (1993) Non-parametric multivariate analyses of changes in community structure. Austral Ecol 18: 117-143

Clarke RK, Gorley RN (2006) PRIMER v6: user manual/ tutorial. PRIMER-E, Plymouth

Clarke RK, Gorley RN (2015) PRIMER v7: user manual/ tutorial. PRIMER-E, Plymouth

* Connell SD (2001) Urban structures as marine habitats: an experimental comparison of the composition and abundance of subtidal epibiota among pilings, pontoons and rocky reefs. Mar Environ Res 52:115-125

Dauby P, Khomsi A, Bouquegneau JM (1998) Trophic relationships within intertidal communities of the Brittany coasts: a stable carbon isotope analysis. J Coast Res 14: 1202-1212

Della-Santina P, Sonni C, Sartoni G, Chelazzi G (1993) Food availability and diet composition of three coexisting Mediterranean limpets (Patella spp.). Mar Biol 116: 87-95

Evans AJ, Firth LB, Hawkins SJ, Morris ES, Goudge H, Moore PJ (2016) Drill-cored rock pools: an effective method of ecological enhancement on artificial structures. Mar Freshw Res 67:123-130

Fairweather PG, Underwood AJ (1983) The apparent diet of predators and biases due to different handling times of their prey. Oecologia 56:169-179

Fairweather PG, Underwood AJ, Moran MJ (1984) Preliminary investigations of predation by the whelk Morula marginalba. Mar Ecol Prog Ser 17:143-156

* Ferrario F, Iveša L, Jaklin A, Perkol-Finkel S, Airoldi L (2016) The overlooked role of biotic factors in controlling the ecological performance of artificial marine habitats. J Appl Ecol 53:16-24

Firth LB, Thompson RC, White FJ, Schofield M and others (2013) The importance of water-retaining features for biodiversity on artificial intertidal coastal defence structures. Divers Distrib 19:1275-1283

Firth LB, White FJ, Schofield M, Hanley ME and others (2016) Facing the future: the importance of substratum features for ecological engineering of artificial habitats in the rocky intertidal. Mar Freshw Res 67:131-143

France RL, Peters RH (1997) Ecosystem differences in the trophic enrichment of $13 \mathrm{C}$ in aquatic food webs. Can J Fish Aquat Sci 54:1255-1258

Fry B (2008) Stable isotope ecology. Springer, New York, NY

* Fry B (2013) Alternative approaches for solving underdetermined isotope mixing problems. Mar Ecol Prog Ser 472: 1-13

Gacia E, Satta M, Martín D (2007) Low crested coastal defence structures on the Catalan coast of the Mediterranean Sea: how they compare with natural rocky shores. Sci Mar 71:259-267

Gin KY, Lin X, Zhang S (2000) Dynamics and size structure of phytoplankton in the coastal waters of Singapore. J Plankton Res 22:1465-1484

* Gittman RK, Fodrie FJ, Popowich AM, Keller DA and others (2015) Engineering away our natural defenses: an analysis of shoreline hardening in the US. Front Ecol Environ 13:301-307

* Glaser R, Haberzettl P, Walsh R (1991) Land reclamation in Singapore, Hong Kong and Macau. GeoJournal 24: 365-373

Grall J, Leloch F, Guyonnet B, Riera P (2006) Community structure and food web based on stable isotopes $\left(\delta^{15} \mathrm{~N}\right.$ and $\delta^{13} \mathrm{C}$ ) analysis of a North Eastern Atlantic maerl bed.
J Exp Mar Biol Ecol 338:1-15

*Hawkins SJ, Hartnoll RG (1980) A study of the small-scale relationship between species number and area on a rocky shore. Estuar Coast Mar Sci 10:201-214

Hawkins SJ, Harding SP, Hutchinson S, Norton TA (1989) A comparison of feeding mechanisms in microphagous, herbivorous, intertidal, prosobranchs in relation to resource partitioning. J Molluscan Stud 55:151-165

* Ido S, Shimrit PF (2015) Blue is the new green - ecological enhancement of concrete based coastal and marine infrastructure. Ecol Eng 84:260-272

Klein JC, Underwood AJ, Chapman MG (2011) Urban structures provide new insights into interactions among grazers and habitat. Ecol Appl 21:427-438

Kohler KE, Gill SM (2006) Coral Point Count with Excel extensions (CPCe): a Visual Basic program for the determination of coral and substrate coverage using random point count methodology. Comput Geosci 32:1259-1269

Koop K, Field J (1980) The influence of food availability on population dynamics of a supralittoral isopod, Ligia dilatata Brandt. J Exp Mar Biol Ecol 48:61-72

* Kwak TJ, Zedler JB (1997) Food web analysis of southern California coastal wetlands using multiple stable isotopes. Oecologia 110:262-277

* Lai S, Loke LHL, Hilton MJ, Bouma TJ, Todd PA (2015) The effects of urbanisation on coastal habitats and the potential for ecological engineering: a Singapore case study. Ocean Coast Manage 103:78-85

Lam NWY, Huang R, Chan BKK (2009) Variations in intertidal assemblages and zonation patterns between vertical artificial seawalls and natural rocky shores: a case study from Victoria Harbour, Hong Kong. Zool Stud 48: 184-195

Kaurand S, Riera P (2006) Trophic ecology of the supralittoral rocky shore (Roscoff, France): a dual stable isotope $\left(\delta^{13} \mathrm{C}, \delta^{15} \mathrm{~N}\right)$ and experimental approach. J Sea Res 56:27-36

KLayman CA, Araujo MS, Boucek R, Hammers CM and others (2012) Applying stable isotopes to examine food-web structure: an overview of analytical tools. Biol Rev Camb Philos Soc 87:545-562

Lee AC, Sin TM (2009) Intertidal assemblages on coastal defence structures in Singapore II. Contrasts between islands and the mainland. Raffles Bull Zool 22:255-268

Lee AC, Tan KS, Sin TM (2009) Intertidal assemblages on coastal defence structures in Singapore I: a faunal study. Raffles Bull Zool 22:237-254

Loke LHL, Todd PA (2016) Structural complexity and component type increase intertidal biodiversity independently of area. Ecology 97:383-393

Loke LHL, Ladle RJ, Bouma TJ, Todd PA (2015) Creating complex habitats for restoration and reconciliation. Ecol Eng 77:307-313

Loke LHL, Liao LM, Bouma TJ, Todd PA (2016) Succession of seawall algal communities on artificial substrates. Raffles Bull Zool 32:1-10

Loke LHL, Bouma TJ, Todd PA (2017) The effects of manipulating microhabitat size and variability on tropical seawall biodiversity: field and flume experiments. J Exp Mar Biol Ecol 492:113-120

Luo Z (1997) An analysis of Hong Kong reclamation and its effect. J Geogr Sci 3:220-227

*Machás R, Santos R (1999) Sources of organic matter in Ria Formosa revealed by stable isotope analysis. Acta Oecol 20:463-469 
Martins GM, Jenkins SR, Neto AI, Hawkins SJ, Thompson RC (2016) Long-term modifications of coastal defences enhance marine biodiversity. Environ Conserv 43: 109-116

McClelland JW, Valiela I, Michener RH (1997) Nitrogenstable isotope signatures in estuarine food webs: a record of increasing urbanization in coastal watersheds. Limnol Oceanogr 42:930-937

*Megina C, González-Duarte MM, López-González PJ, Piraino S (2013) Harbours as marine habitats: hydroid assemblages on sea-walls compared with natural habitats. Mar Biol 160:371-381

Moreira J, Chapman MG, Underwood J (2007) Maintenance of chitons on seawalls using crevices on sandstone blocks as habitat in Sydney Harbour, Australia. J Exp Mar Biol Ecol 347:134-143

Moschella PS, Abbiati M, Åberg P, Airoldi L and others (2005) Low-crested coastal defence structures as artificial habitats for marine life: using ecological criteria in design. Coast Eng 52:1053-1071

Murthy RC, Rao Y, Inamdar AB (2001) Integrated coastal management of Mumbai metropolitan region. Ocean Coast Manage 44:355-369

Notman GM, McGill RAR, Hawkins SJ, Burrows MT (2016) Macroalgae contribute to the diet of Patella vulgata from contrasting conditions of latitude and wave exposure in the UK. Mar Ecol Prog Ser 549:113-123

Pennings SC, Carefoot TH, Zimmer M, Danko JP, Ziegler A (2000) Feeding preferences of supralittoral isopods and amphipods. Can J Zool 78:1918-1929

Perkol-Finkel S, Airoldi L (2010) Loss and recovery potential of marine habitats: an experimental study of factors maintaining resilience in subtidal algal forests at the Adriatic Sea. PLOS ONE 5:e10791

Perkol-Finkel S, Ferrario F, Nicotera V, Airoldi L (2012) Conservation challenges in urban seascapes: promoting the growth of threatened species on coastal infrastructures. J Appl Ecol 49:1457-1466

Phillips DL, Gregg JW (2003) Source partitioning using stable isotopes: coping with too many sources. Oecologia 136:261-269

* Phillips DL, Newsome SD, Gregg JW (2005) Combining sources in stable isotope mixing models: alternative methods. Oecologia 144:520-527

Pister B (2009) Urban marine ecology in southern California: the ability of riprap structures to serve as rocky intertidal habitat. Mar Biol 156:861-873

Qvarfordt S, Kautsky H, Malm T (2006) Development of fouling communities on vertical structures in the Baltic Sea. Estuar Coast Shelf Sci 67:618-628

R Core Team (2013) R: a language and environment for sta-

Editorial responsibility: Lisandro Benedetti-Cecchi, Pisa, Italy tistical computing. R Foundation for Statistical Computing, Vienna. www.R-project.org

Ravinesh R, Bijukumar A (2013) Comparison of intertidal biodiversity associated with natural rocky shore and sea wall: a case study from the Kerala coast, India. Indian J Geo-Mar Sci 42:223-235

* Schaal G, Riera P, Leroux C, Grall J (2010) A seasonal stable isotope survey of the food web associated to a peri-urban rocky shore. Mar Biol 157:283-294

* Steinarsdóttir MB, Ingólfsson A, Ólafsson E (2009) Trophic relationships on a fucoid shore in south-western Iceland as revealed by stable isotope analyses, laboratory experiments, field observations and gut analyses. J Sea Res 61: 206-215

* Steneck RS, Watling L (1982) Feeding capabilities and limitation of herbivorous molluscs: a functional group approach. Mar Biol 68:299-319

Taylor JD (1976) Habitats, abundance and diets of muricacean gastropods at Aldabra Atoll. Zool J Linn Soc 59:155-193

* Thompson RC, Crowe TP, Hawkins SJ (2002) Rocky intertidal communities: past environmental changes, present status and predictions for the next 25 years. Environ Conserv 29:168-191

Thompson RC, Norton TA, Hawkins SJ (2004) Physical stress and biological control regulate the balance between producers and consumers in marine intertidal biofilms. Ecology 85:1372-1382

Todd PA, Chou LM (2005) A tale of survival: Labrador Park, Singapore. Coral Reefs 24:391

*Underwood A (1981) Structure of a rocky intertidal community in New South Wales: patterns of vertical distribution and seasonal changes. J Exp Mar Biol Ecol 51:57-85

*Underwood AJ, Clarke KR (2005) Solving some statistical problems in analyses of experiments on choices of food and on associations with habitat. J Exp Mar Biol Ecol 318: $227-237$

Vadas RL Sr, Johnson S, Norton T (1992) Recruitment and mortality of early post-settlement stages of benthic algae. Br Phycol J 27:331-351

* Vanderklift MA, Ponsard S (2003) Sources of variation in consumer-diet ${ }^{15} \mathrm{~N}$ enrichment: a meta-analysis. Oecologia 136:169-182

Vaselli S, Bulleri F, Benedetti-Cecchi L (2008) Hard coastaldefence structures as habitats for native and exotic rocky-bottom species. Mar Environ Res 66:395-403

*Williams GA (1993) Seasonal variation in algal species richness and abundance in the presence of molluscan herbivores on a tropical rocky shore. J Exp Mar Biol Ecol 167:261-275

Winer BJ (1971) Statistical principles in experimental design. McGraw-Hill, Tokyo

Submitted: March 3, 2017; Accepted: November 6, 2017 Proofs received from author(s): January 18, 2018 